\title{
ASAS FIRST TO FILE PRINCIPAL DALAM KASUS HAK MEREK NAMA TERKENAL BENSU
}

\author{
Humaedi Abdurahman \\ Alumni Program Studi Magister Ilmu Hukum \\ Pascasarjana Universitas Islam Bandung \\ Email : Humaediabd04@gmail.com
}

\begin{abstract}
Abstrak : Penelitian ini dilatar belakangi adanya sebuah sengketa merek terkenal dengan nama bensu, timbul permasalahan dalam hal ini Undang-Undang Nomor 20 Tahun 2016 tentang Merek dan Indikasi Geografis menganut sistem konstitutif. Penelitian ini menggunakan pendekatan yuridis normatif dengan metode deskriptif, dan analisis menggunakan library research. Hasil penelitian yang di dapat bahwa gugatan yang diajukan oleh Ruben Onsu atas Jesy Handalim tidak diterima oleh majelis hakim. Dan sistem pendaftaran merek di Indonesia menganut asas first to file principal dimana pendaftar pertama mendapatkan hak ekslusif dan perlindungan hukum. Akibatnya jika merek terkenal atau nama terkenal ingin dijadikan merek dagang wajib di daftarkan karena jika tidak tidak memiliki kekuatan hukum secara yuridis, berdampak merugikan pemilik karena tidak memiliki perlindungan dan hak ekslusif.
\end{abstract}

Kata Kunci : Hak Merek, First File To Principal, Konstitutif.

Abstract: This study was motivated by a dispute over the use of the name "Bensu". Ruben Onsu who is a public figure thought that this name is a famous name attached to him. However, his business trademark registration activity at Directorate General of Intellectual Property Rights (Ditjen HAKI) under the name "Bensu" is hampered because it has been used by "Bengkel Susu (Bensu)") owned by Jesy Reliimim since Law Number 20 Year 2016 concerning Trademarks and Geographical Indications adheres to a constitutive system. The purpose of this study is to understand the implementation of the first to file principle in the case of brand rights of Ruben Onsu. The method used a normative juridical approach using descriptive method, and analyzed using library research. The result shows that the lawsuit filed by Ruben Onsu against Jesy Reliimim was not accepted by the panel of judges. Additionally, the trademark registration system in Indonesia adheres to first to file principle where the first registrant gets exclusive rights and legal protection. As a result, if a famous brand or name wants to be a trademark, it must be registered to have legal force legally. In addition, if it is not conducted, it will give an adverse impact on the owner because it does not have protection and exclusive rights.

Keywords: Brand Rights, First File to Principle, Constitutive.

\section{A. PENDAHULUAN \\ 1. Latar Belakang}

Perdagangan di Indonesia juga sangat erat hubungannya dengan adanya suatu Merek, oleh sebab itu dibutuhkan adanya suatu peraturan yang dapat memberikan jaminan perlindungan dan kepastian hukum, khususnya di bidang merek yang saat ini telah diatur di dalam Undang-Undang Nomor 20 
Tahun 2016 Tentang Merek dan Indikasi Geografis sehingga dapat melindungi seluruh pelaku ekonomi di Indonesia dan dapat menciptakan persaingan usaha secara sehat, sebab merek sangat penting dalam dunia perdagangan khususnya dalam hal pemasaran produk karena konsumen sering kali mengaitkan merek dengan kualitas dan reputasi dari suatu barang dan jasa.

Yang dimaksud dengan merek merek. berdasarkan Pasal 1 angka 1 UU 20/2016 tentang Merek dan Indikasi Geografis adalah tanda yang ditampilkan secara grafis berupa gambar, logo, nama, kata, huruf, angka, susunan warna, dalam bentuk (dua) dimensi dan atau 3 (tiga) dimensi, suara, hologram, atau kombinasi dari (dua) atau lebih unsur tersebut untuk membedakan barang dan/atau jasa yang produksi oleh orang atau badan hukum dalam kegiatan perdaganagn barang dan/atau jasa. Dari pengertian tersebut, merek dapat diartikan sebagai daya pembeda dalam suatu barang dan jasa.

Arti suatu nama mungkin bagi sebagian orang tidaklah begitu penting, namun bagi sebagian yang lain terutama bagi pengusaha nama adalah sesuatu yang sangat berarti untuk memberikan tanda dari produk yang dihasilkan dengan maksud menunjukkan asal-usul barang (indication of origin) (Muhamad Djumhana, R Djubaedillah, 1997 : 149) sehingga dapat dibedakan dengan produk produk maupun jasa lainnya. Serta melindungi hasil produksi suatu perusahaan terhadap hasil produksi perusahaan lain yang sejenis maupun yang tidak sejenis.

Merek sangat penting dalam dunia industri dan perdagangan khususnya dalam hal pemasaran produk kepada calon konsumen. Merek selain sebagai harta kekayaan yang dapat menghasilkan keuntungan bagi pemiliknya, juga sebagai alat untuk melindungi masyarakat sebagai konsumen dari terjadinya pemalsuan terhadap kualitas tertentu. (Khoirul Hidayah, 2013 : 72).

Merek memegang peranan yang sangat penting di bidang industri barang dan jasa karena merek tidak hanya digunakan sebagai identifikasi produk baik itu berupa barang ataupun jasa, tetapi juga menjadi alat startegi bisnis dalam rangka memenangkan persaingan usaha yang saat ini kompetitif. (Mas Rahmah. 2004. Perlindungan Hukum 
Merek Menurut UU 15 /2001. Jurnal Yuridika, Volume 19 Nomor 5 : 388).

Sebagai bagian dari Hukum hak atas kekayaan intelektual maka suatu merek jelas akan dilindungi dalam penggunaan dan pemakaiannya. Untuk dapat dilindunginya suatu merek, maka merek tersebut terlebih dahulu harus didaftarkan. Pendaftaran tersebut menjadi penting untuk mendapatkan hak atas merek tersebut. Hak atas merek adalah hak eksklusif yang diberikan negara kepada pemilik merek yang terdaftar dalam "daftar umum merek" untuk jangka waktu tertentu. (Oksidelfa Yanto : 25).

Indonesia sendiri menganut sistem pendaftar pertama disebut juga first to file principle. Artinya, merek yang didaftar adalah yang memenuhi syarat dan sebagai yang pertama. Kemudian sistem pendaftaran berubah menjadi first to file. Artinya, dalam sistim hukum merek. Indonesia menganut dan menerapkan sistim first to file, yang berarti, siapa yang mendaftar lebih dahulu, maka dialah yang berhak. Namun demikian sistem first to file tersebut memiliki kelemahan yang berarti. (Ibid : 26).

Dengan demikian apabila seseorang atau suatu badan telah mendaftar suatu merek, maka pihak lain tidak boleh lagi mendaftar dengan merek yang sama. Jika ingin juga mendaftar atau ingin memakai merek yang sama, maka pihak lainnya tersebut harus terlebih dahulu meminta izin kepada si pemilik merek pertama.

Hal ini sesuai dengan sistem hukum merek yang dianut Indonesia yaitu first to file. Artinya, siapa yang lebih dahulu mendaftar atau memperoleh sertifikat merek, dialah yang berhak atas merek tersebut. Pihak lain tidak dibolehkan mendaftarkan suatu merek dengan nama yang sama.

Dengan suatu merek, perusahaan yang memproduksi barang akan mudah dikenal masyarakat. Apabila merek tersebut sudah dikenal oleh masyarakat, akan menaikkan reputasi merek produk tersebut sehingga apabila terjadi pelanggaran misalnya pembajakan atau peniruan merek terkenal yang dirugikan adalah pemilik merek pertama yang sah. (Arfi Dyah Chatarina, 2019 : 117).

Perlindungan terhadap hak atas merek baru akan di peroleh setelah merek tersebut terdaftar, hal ini sesuai dengan ketentuan yang tercantum dalam Pasal 3 Undang- Undang Nomor 20 Tahun 2016 tentang Merek dan Indikasi Geografis. Perlindungan hukum merek 
yang diberikan kepada merek terdaftar, dapat berupa perlindungan hukum preventif atau perlindungan hukum refresif. (Haedah Faradz, 2008, Perlindungan Hak Atas Merek, Jurnal Dinamika Hukum, 8(1) : 3).

Pendaftaran merek melahirkan hak eksklusif kepada pemilik merek untuk dalam jangka waktu tertentu (selama 10 tahun, dan bisa diperpanjang setiap sepuluh tahun sekali) menggunakan sendiri merek tersebut atau memberi izin kepada pihak lain untuk menggunakan mereknya tersebut melalui suatu perjanjian. Pencegahan terhadap pelanggaran atas permohonan pendaftaran merek yang sudah lebih dahulu ada atau telah terdaftar dapat dilakukan dengan penerapan sistem First To File Principle. Di mana prinsip tersebut menekankan pada perlindungan terhadap pemilik hak merek terdaftar yang "beritikad baik" atau sudah terlebih dahulu tercatat sebagai pendaftar pertama. (Echa Cristi, 2020 : 2).

Untuk merek terkenal perlindungan yang diberikan bagi merek tersebut dilakukan dengan dua cara yaitu perlindungan hukum preventif dan perlindungan hukum secara refresif. Definisi orang terkenal tidak diatur secara eksplisit didalam peraturan Undang - Undang Merek dan Indikasi Geografis, tetapi menurut Kamus Besar Bahasa Indonesia definisi dari orang adalah yang berkaitan dengan manusia yang secara pribadi. Sedangkan definisi terkenal dala Kamus Besar Bahasa Indonesia adalah dikenal atau diketahui umum, termasyhur dan/atau tersohor. Sehingga bias ditarik kesimpulan definisi dari orang terkenal yaitu, manusia secara pribadi yang dikenal atau diketahui secara umum oleh masyarakat luas. Dapat ditarik contoh, Ruben Onsu adalah seseorang yang telah dikenal atau diketahui oleh masyarakat luas, beliau seorang public figure yang berprofesi sebagai seorang artis dan telah sering muncul di berbagai stasiun televise Indonesia. (Citta Nirmala Anindita Palupi, 2019 : $3)$.

Dalam praktik ada sebuah sengketa antara orang terkenal yaitu ruben onsu dengan Jesy Handalim pemelik cafe dan bar yang bernama Bengke Susu yang disingkat Bensu. Ruben Onsu mengajukan gugatan tersebut atas dasar bahwa usaha geprek bensu yang dijalankan oleh ruben terhambat karena gagal mendaftarkan merek ke Direktorat Merek, Ditjen Hak 
Kekayaan Intelektual (DJKI) pada Kementerian Hukum dan Hak Asasi manusia. Pasalnya, sudah ada yang mendaftarkan merek Bensu sebelum Ruben. Pemegang nama bensu pertama yang terdaftar adalah Jesy Handalim memegang sertifikat merek Bensu dengan nomor IDM000622427 yang dinyatakan terdaftar sejak 7 Juni 2018 dan bakal kedaluwarsa pada 3 September 2025. Pendaftaran merek tersebut dilakukan pada tanggal 3 September 2015 Dari data World Intellectual Property Organization yang terintegrasi dengan data Direktorat Merek DJKI, Jessy Handalim beralamat di Bandung, Jawa Barat. (www.tempo.co).

Ruben Onsu bersikukuh atas nama bensu tersebut karena sudah mendapatkan penetapan Pengadilan Negeri Jakarta Selatan, yang pada akhirnya Pengadilan Negeri Jakarta Selatan melalui Penetapan Nomor : 384/Pdt.P/2018/PN.Jkt.Sel. telah menetapkan, yang salah satu amarnya : "Menyatakan bahwa sah dan mempunyai kekuatan hukum atas penetapan nama BENSU merupakan singkatan nama dari Ruben Samuel Onsu alias Ruben Onsu".

\section{Identifikasi Masalah}

Berdasarkan latar belakang tersebut penulis mengidentifikasi permasalahan sebagai berikut:

1. Bagaimanakah penerapan asas first to file principal dalam kasus hak merek dengan menggunakan nama orang terkenal?

2. Bagaimanakah akibat hukum jika nama orang terkenal yang dijadikan merek dagang belum terdaftar di Dirjen HAKI?

\section{Metode Penelitian}

Penelitian ini menggunakan pendekatan yuridis normatif, dengan metode deskriptif analitis yaitu menjelaskan dan menggambarkan terkait dengan asas first to file principal dalam kasus hak merek nama orang terkenal, beserta akibat hukumnya jika nama orang terkenal yang dijadikan merek dagang namun belum terdaftar. Penelitian ini menggunakan library research, dengan data dari berita media online, jurnal, artikel dan hasil penelitian sebagai bahan untuk menjawab masalah penelitian.
B. PEMBAHASAN
1. Penerapan Asas First to File Principal Dalam Kasus Hak Merek Dengan Menggunakan Nama Orang Terkenal 
Hak Kekayaan Intelektual adalah terjemahan resmi dari Intellectual Property Rights. Yaitu hak yang timbul dari hasil olah pikir manusia yang menghasilkan suatu produk atau proses yang berguna untuk kepentingan manusia serta bernilai ekonomi. Tujuan utama sistem Hak Kekayaan Intelektual adalah menjamin agar proses kreatif tersebut terus berlangsung dengan menyediakan perlindungan hukum yang memadai dan menyediakan sanksi terhadap pihak yang menggunakan proses kreatif tersebut tanpa izin. (Tomi Suryo Utomo, $2010: 2$ ).

\section{World Intelectual Property} Organization (WIPO), adalah organisasi Internasional yang mengurus bidang Hak Kekayaan Intelektual membagi ruang lingkup Hak Kekayaan Intelektual dalam 2 (dua) bagian, yaitu:

a. Hak Cipta (copyright), dan

b. Hak Kekayaan Industri (industrial property rights), antara lain meliputi: Paten (patent), Desain Industri (industrial design), Merek (trademark), Indikasi Geografis (geographical indication), Desain Tata Letak Sirkuit Terpadu (layout design of integrated circuit), Rahasia Dagang (trade secret), dan
Perlindungan Varietas Tanaman

(Plant Variety Protection).

Konvensi yang mengatur tentang merek secara Internasional adalah yaitu The Paris Convention For the Protection of Industrial Property (Konvensi Paris untuk Perlindungan Hak Milik Perindustrian), atau biasa di sebut Konvensi Paris. Konvensi ini berasaskan pada perlindungan yang sama kepada warga negara dari setiap negara peserta Uni Paris tersebut, bila telah memenuhi syarat (national treatment). Secara garis besar, ketentuan-ketentuan yang di atur dalam Konvensi Paris antara lain: kriteria pendaftaran, hilangnya merek dagang karena tidak digunakan, perlindungan khusus bagi merek-merek dagang terkenal, merek dagang jasa dan merek dagang kolektif, serta pengalihan merek. (Ana Sofiana, Perlindungan Merek Secara Internasional, www.Kompasiana.com).

Berdasarkan pada Konvensi Paris, telah di bentuk pula suatu Agreements, yaitu perjanjian Madrid 1891. Di bentuk pada tanggal 14 April 1891, bertujuan untuk mempermudah cara pendaftaran merek-merek di berbagai negara secara sekaligus, yaitu di negara peserta Uni Paris. Hal tersebut 
dimaksudkan untuk menghindari pemberitahuan asal barang secara palsu (Madrid Agreement Concerning The Repression of False Indications of Origin/biro Internasional di Berne Swiss), yaitu merek-merek yang akan didaftarkan secara bersamaan tersebut harus terlebih dahulu terdaftar sebagai merek nasional di negara asalnya. (Echa Cristi, Op. Cit : 19).

Perjanjian lanjutan mengenai merek tersebut, yaitu perjanjian Den haag, yang di bentuk pada 06 November 1925 mengenai Deposit Internasional tentang Gambar- Gambar atau Model Kerajinan (The Hague Arrangement Concerning The International Deposit Of Industrial Patern and Design). Di samping itu ada juga perjanjian lain, yaitu Agreement Lisabon mengenai perlindungan pendaftaran Internasional mengenai keterangan-keterangan asal barang (Lisbon Agreement Concerning The Protection and The Internasional Registration Of Declaration Of Origin, 31 Oktober 1938). Dan Agreement Nice mengenai klasifikasi Internasional berkenaan dengan merek (Nice Agreement Concerning The International Classification of Good and Services to Which Trademarks
Apply, 15 Juni 1957). (Muhammad Djumhana, Djubaedillah, 2003 : 185).

Mulai tahun 1953, Indonesia menjadi anggota Uni Paris setelah menyatakan permohonan tertulis Pemerintah Indonesia kepada Pemerintah Swiss sebagai penyimpan (depositiry state), yaitu naskah perjanjian multilateral Konvensi Paris tersebut. Dengan adanya pernyataan secara sepihak untuk turut serta pada Konvensi Paris tersebut, maka meskipun tidak di ratifikasi oleh parlemen negaranya, tetapi dengan diterimanya permohonan menjadi anggota oleh konvensi, maka secara otomatis negara tersebut menjadi anggota Uni Paris sesuai dengan Pasal 18 ayat (2) Konvensi Paris. Dalam hal inipun peserta terdahulu tidak diberikan kesempatan untuk melakukan oposisi terhadap pernyataan suatu negara untuk menjadi anggota Uni Paris. (Ibid : 164).

Hak merek di kenal pertama kali pada masa penjajahan Belanda yaitu dengan dikeluarkannya Undang-Undang Hak Milik Perindustrian yang tercantum di dalam "Reglement Industriele Eigendom Kolonien", kemudian pada masa penjajahan Jepang dikeluarkan peraturan merek yang di kenal dengan "Osamu Seirei" Nomor 30 tentang 
Menyambung Pendaftaran Cap Dagang.

Selanjutnya

peraturan-peraturan

tersebut di ganti dengan UndangUndang Nomor 21 Tahun 1961 tentang Merek Perusahaan dan Merek Perniagaan. Prinsip pertama yang di atur dalam Undang-Undang ini adalah hak merek diperoleh melalui pemakaian pertama (first to use system atau stelsel deklaratif). First to use system atau stelsel deklaratif artinya anggapan hukum timbul bahwa pemakai pertama adalah pihak yang berhak atas merek tersebut.

Selanjutnya, di ganti dengan Undang-Undang Nomor 19 Tahun 1992 tentang Merek, dengan beberapa perubahan mendasar yaitu judul yang di pilih adalah "Undang-Undang Merek" sehingga bersifat sederhana namun mencangkup pengaturan yang luas; perubahan yang menyangkut sistem perolehan hak yang semula first to use system atau stelsel deklaratif menjadi sistem pendaftar pertama (First To File System atau stelsel konstitutif), artinya anggapan hukum timbul bahwa pemohon pertama yang mengajukan pendaftaran merek dengan itikad baik adalah pihak yang berhak atas merek tersebut. Penggunaan sistem konstitutif ini dimaksudkan agar lebih menjamin kepastian hukum; dalam UndangUndang ini di atur terkait dengan pendaftaran merek dengan hak prioritas; dan pengaturan sanksi pidana baik untuk tindak pidana dengan kualifikasi kejahatan maupun pelanggaran.

Penyesuaian terhadap ketentuan Trade Related Aspect of Intellectual Property Right Including Trade In Counterfeit Goods (TRIP's), di ubah kembali dengan Undang-Undang Nomor 14 Tahun 1997 tentang Merek. Tetapi, pengaturan dan penyempurnaan tentang merek di anggap tidak praktis.

Selanjutnya, pada tahun 2001 di ganti dengan Undang-Undang Nomor 15 Tahun 2001 tentang Merek. Dan terakhir, peraturan terkait dengan merek disempurnakan lagi dengan diundangkannya Undang-Undang Nomor 20 Tahun 2016 tentang Merek dan Indikasi Geografis. Adapun yang menjadi pertimbangannya adalah sejalan dengan konvensi-konvensi Internasional yang telah di ratifikasi oleh Indonesia, maka dirasakan peranan merek menjadi sangat penting terutama untuk menjaga persaingan usaha yang tidak sehat di era perdagangan bebas. Untuk itu, diperlukan pengaturan yang memadai tentang merek guna 
memberikan peningkatan pelayanan bagi masyarakat.

\section{Asas First to File Principal Pada Nama Orang Terkenal Dalam Hak Merek Bensu}

Produk-produk dengan merek yang terkenal akan lebih mudah untuk dipasarkan, sehingga dapat dengan lebih mudah untuk dijual dan memberikan keuntungan finansial yang lebih besar. Pengertian Merek terkenal yaitu, apabila suatu Merek telah beredar keluar dari batas-batas regional sampai batas- batas internasional, dimana telah beredar keluar negeri asalnya dan dibuktikan dengan adanya pendaftaran Merek yang bersangkutan di berbagai Negara. Dengan begitu maka dibutuhkan perlindungan hukum bagi Hak Merek Terkenal untuk menjamin adanya kepastian hukum bagi para penemu merek, pemilik merek dan pemegang hak merek. Selain itu juga untuk mencegah terjadinya pelanggaran dan kejahatan atas Hak Merek dan memberikan manfaat bagi kepada masyarakat agar masyarakat lebih terdorong untuk membuat dan mengurus pendaftaran merek usahanya. (Iswi Hariyani. 2010 : 89).

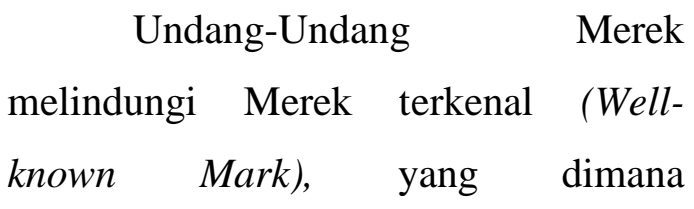

permohonan merek akan ditolak jika mempunyai persamaan pada pokoknya atau keseluruhannya dengan Merek Terkenal untuk barang dan/atau jasa yang sejenis. (Ni Ketut Supasti Dharmawan dkk, 2016 : 58).

Perlindungan hukum terhadap Hak Merek Terkenal di Indonesia diatur berdasarkan Undang- Undang Nomor 20 Tahun 2016 tentang Merek dan Indikasi Geografis, tepatnya pada Pasal Pasal 21 ayat (1) huruf b dan c, Pasal 83 ayat (2), dan diperkuat oleh Penjelasan Pasal 21 ayat (1) huruf b, Penjelasan Pasal 76 ayat (2), dan Penjelasan Pasal 83 ayat (2).

Berlakunya Undang-Undang Merek di Indonesia hal-hal yang berkaitan dengan pencatutan, pendomplengan, penggunaan nama maupun domain name atas suatu merek yang telah terkenal merupakan musuh besar bagi perkembangan industri sebuah perusahaan. (Usman, Rachmadi, $2003: 45)$.

$$
\text { Pada kasus sengketa nama }
$$
terkenal Ruben Onsu dengan Jesy Handalim pemilik bengkel susu yang menggunakan nama singkatan Bensu. Ruben Onsu dengan PT nya yang bernama PT. Onsu Pangan Perkasa merasa dirugikan sebab merek sedang 
menguruskan hak merek atas produkproduk mereka seperti Bensu Sosis, Bensu Bakso, Bensu Nugget, Geprek Bensu, Bensu Otak-otak, dan Bensu Drink + Lukisan. Namun status pengajuannya tertunda karena nama Bensu terlebih dahulu ada yang menggunakan dan mendaftarkan di dirjen HAKI atas nama Jesy Handalim yang terdaftar dengan nomor Nomor IDM000622427 produk/jasa pada kelas barang 43 yaitu jasa bar, kafe, kantin, katering, penyewaan kursi, meja, taplak meja, peralatan terbuat dari kaca, restoran, restoran swalayan, kafetaria, tempat makan yang menghidangkan kudapan, penyewaan dispenser air minum.

Hal tersebut merugikan bagi PT.

Onsu Pangan Perkasa karena sang pemilik merupakan publik figure yang terkenal dan namanya pun sudah mendapatkan pengukuhan dari Pengadilan Negeri Jakarta Selatan dengan Nomor

384/Pdt.P/2018/PN.Jkt.Sel. sehingga sang pemilik Ruben Onsu mengajukan gugatan ke Pengadilan Niaga Jakarta Pusat dengan Nomor Register 48/Pdt.Sus-HKI/Merek/2018/PN Niaga Jkt.Pst dalam petitum gugatan tersebut ruben onsu menuntut kepada Majelis
Hakim Pengadilan Niaga Jakarta Pusat untuk membatalkan merek Bensu yang terdaftar oleh Jesy Handalim dengan Nomor IDM000622427 dalam Kelas 43, selain itu Ruben Onsu juga menuntut untuk menyatakan bahwa Bensu adalah singkatan nama orang terkenal, alias namanya sendiri dan enyatakan merek Geprek Bensu milik penggugat (Ruben) adalah merek terkenal.

Bahwa Sertifikat merek Bensu diberikan Ditjen HKI kepada Jessy pada 7 Juni 2018. Masa berlakunya baru habis pada 3 September 2025. Masa berlaku sertifikat berlaku selama sepuluh tahun, sejak Jessy mengajuksan pendaftaran pada 3 September 2015. Dan ketika di publikasikan tidak ada yang keberatan pada saat itu. (Anggar Septiadi, 2018, Merek Bensu Jadi Rebutan, ini kata Ditjen HKI. www.nasional.kontan.co.id).

Seiring berjalannya waktu pada tanggal 07 Februari 2019 Pengadilan Niaga Jakarta Pusat menyatakan gugatan Penggugat (Ruben Onsu) tidak daat diterima, dengan alasan bahwa ebagaimana ketentuan Undang-Undang No. 20 Tahun 2016 tentang Merek dan Indikasi Geografis (UU MIG), seharusnya Penggugat menempuh 
terlebih dahulu mekanisme PERMOHONAN BANDING kepada Menteri, dan menunggu putusan banding dari KOMISI BANDING MEREK, dan jika pada akhirnya diputuskan menolak permohonan banding, maka barulah Penggugat menempuh upaya gugatan ke Pengadilan Niaga. Dengan kata lain, gugatan pembatalan merek yang diajukan Penggugat (Ruben Onsu) di Pengadilan Niaga adalah PREMATURE.

Maka dengan tidak diterimanya gugatan tersebut berimplikasi bahwa Jesy Handalim merupakan pemegang hak merek Bensu dan terdapat hak ekslisif bagi pendaftar bagi merek tersebut. selain itu memberikan penjelasan pula kepada masyarakat bahwa di Indonesia menerapkan asas first to file principal dalam pendaftaran merek di Indonesia, sehingga sistem kostitutif yang digunakan bukan sistem deklatarif, hal ini yang dimaksud dalam Undang-Undang No 20 Tahun 2016.

Meskipun Penggugat (ruben onsu) mendalilka bahwa namanya merupakan nama terkenal dan prodaknya merupakan produk terkenal, namun belum terdaftar sesuai dengan ketentuan perundang-undangan yang berlaku sehingga secara yuridis hal ini belum bisa dianggap sebagai merek terkenal. Padahal dalam pasal 21 ayat (2) a Undang-Undang No. 20 Tahun 2016 menjelaskan bahwa Dirjen Kekayaan Intelektual (DJKI) wajib menolak pendaftaran merek jika merupakan nama atau singkatan nama dari orang terkenal.

Dalam fakta dipersidangan saksi ahli dari pihak Penggugat pun menjelaskan

a. Bahwa suatu merek dianggap sebagai merek terkenal jika, mempunyai reputasi merek yang diperoleh karena promosi yang gencar dan besar-besaran, bukti pendaftaran merek dimaksud di indonesia dan beberapa negara lain dan mempunyai kualitas tertentu; dan jika tidak memenuhi hal-hal tersebut, maka suatu merek tidak bisa disebut sebagai merek terkenal.

b. Bahwa jika suatu pihak mendalilkan mempunyai merek terkenal, sedangkan baru pada tahap permohonan dan belum ada satu pun bukti pendaftaran baik di indonesia maupun di negara lain, maka yang bersangkutan dianggap mereknya belum ada, jadi tidak bisa dianggap sebagai merek terkenal.

Maka dengan adanya putusan tersebut pasal 21 ayat (2) a memberikan penjelasan selain harus memang dikenal dan juga terdaftar sehingga memenuhi kekuatan secara yuridis. 
Bahwa penerapan prinsip "first to file" dalam pendaftaran merek bisa dilihat juga dalam putusan merek sebelumnya yang menarik banyak perhatian yaitu Putusan Peninjauan Kembali Mahkamah Agung dalam kasus "Pierre Cardin", dimana merek Pierre Cardin tersebut dimenangkan oleh orang Indonesia yang bernama Alexander Satryo Wibowo yang mendapatkan hak merek itu dari hak eksklusif merek Pierre Cardin yang terdaftar pada 29 Juli 1977, sedangkan pemilik 'asli' merek Pierre Cardin (orang Perancis) baru mendaftarkannya di Indonesia tahun 1999 atau setelahnya. Majelis Hakim PK pun menilai bahwa pendaftaran merek Alexander Satryo Wibowo tidak memiliki maksud untuk mendompleng merek milik Pierre Cardin Prancis, sehingga sesuai Undang-Undang Merek tidak dapat dikualifikasikan memiliki itikad tidak baik.

Bahwa dengan demikian meskipun nama bensu sudah mendapat pengukuhan dari Pengadilan Negeri Jakarta Selatan atas nama yang melekat pada nama Ruben Samuel Unsu alias Ruben Onsu, dan Bensu sudah menjadi nama panggung sejak tahun 2006, hal tersebut tidak dijadikan dasar, karena dalam UU Merek di Indonesia menganut sistem konstitutif dimana asas first to principal yang dipegang, sehingga yang mendaftar pertama yang memegang hak ekslusif dan patut untuk mendapatkan perlindungan hukum.

Dengan pendaftaran merek pemilik merek memiliki kewenangan :

a. Hak untuk menggunakan atau mengizinkan orang lain untuk menggunakan mereknya ;

b. Hak untuk melarang orang lain menggunakan mereknya ;

c. Hak untuk mengalihkan dan/atau melisensikan hak mereknya.

Sehingga berdasarkan sistem konstitutif dan berdasarkan putusan dari Pengadilan Niaga Jakarta Pusat atas sengketa Hak Merek nama Bensu dengan doktrin "prior $i$ filling" bahwa yang berhak atas suatu merek adalah pihak yang mendaftar mereknya dikenal dengan asas presumption of ownership. (Muhammad Djumhana, R Djubaedillah. Op. Cit : 255).

Dengan mendaftarkan mereknya maka pemilik merek akan mendapatkan perlindungan, dan kelebihan dari sistem ini adalah kepastian hukum. Maka meskipun nama terkenal, bukan berarti menjadi jaminan jika dijadikan suatu 
merek akan langsung mendapat perlindungan dan hak ekslusif, tetap harus di daftarkan ke DJKI agar memiliki kekuata hukum secara yuridis.

Asas first to file principle dalam sistem konstitutif bukan tanpa kelemahan, asas ini tentunya memiliki kelemahan seperti membuka peluang timbulnya pembajakan suatu merek terutama sekali merek dagang yang dimiliki pihak asing. Artinya, banyak merek terkenal yang didaftarkan oleh bad applicant (pendaftar beritikad buruk).

Terlebih pihak Ditjen HAKI belum mempertimbangkan alasan merek terkenal dalam oposisi, sebelum adanya putusan pengadilan bahwa merek terkenal tersebut merasa keberatan.

Maka dari itu patut menjadi perhatian bagi kita semua terutama public figure yang namnya sudah terkenal dan ingin dijadikan merek dagang, maka harus cepat mendaftarkan merek tersebut. agar memiliki kekutan hukum, karena jika tidak ada kemungkinan di daftarkan terlebih dahulu oleh pihak lain meskipun beritikad baik tidak mendompleng nama terkenal tersebut.
Karena dalam sistem konstitutif dengan asas first to file prinsipal hak ekslusif dan perlindungan hukum di dapat setelah di daftarkan. (Sudargo Gautama, R. Winata. 1997 : 5).

Bentuk perlindungan hukum bersifat preventif jika telah di daftarkan, dan bisa berubah menjadi represif seperti yang tercantum dalam UU Merek bahwa memperdagangkan barang tiruan yang menggunakan merek (brand) terkenal dapat dikategorikan pelanggaran UU Merek yang memuat sanksi pidana, sesuai ketentuan Pasal 100-102 Undang-Undang Nomor 20 Tahun 2016 tentang Merek dan Indikasi Geografis, yang dimana bagi orang yang memperdagangkan barang tiruan dan barang tersebut merupakan hasil tindak pidana diancam pidana penjara paling lama 5 (lima) tahun dan/atau pidana denda paling banyak Rp2.000.000.000,00 (dua miliar rupiah). Pelanggaran atas Hak Merek Terkenal di Indonesia dapat dimasukan sebagai kasus kriminal (pidana) maupun perdata. Pemilik Merek terdaftar dapat mengajukan gugatan kepada pihak lain, yaitu pihak yang secara sengaja dan tanpa hak menggunakan/meniru Merek yang mempunyai persamaan pada pokoknya atau seluruhnya dengan 
barang dan atau jasa Merek Terkenal. (Ahmadi Miru, 2005 : 78).

\section{PENUTUP}

\section{Kesimpulan}

1. Berdasarkan hal tersebut dapat disimpulkan bahwa sistem pendaftaran merek di Indonesia berdasarkan Undang-Undang No. 20 tahun 2016 tentang Merek dan Indikasi Geografis menganut sistem konstitutif dengan asas first to file principal dimana pendaftar pertama yang mendapat perlindungan dan hak ekslusif atas merek tersebut. bahkan atas nama terkenal sekalipun dalam kasus sengketa Ruben Onsu dengan Bengkel Susu (Bensu) memberikan implikasi bahwa meskipun nama terkenal belum ada jaminan perlindungan hukum seperti yang dijelaskan dalam pasal 21 ayat (2) a karena tetap perlu di daftarkan di Dijem HaKI Kementrian Hukum dan HAM.

2. Akibatnya jika nama terkenal menjadi merek dagang yang belum terdaftar tidak akan memiliki kekuatan hukum, jika ada yang mendaftar atas nama tersebut meskipun dengan itikad baik beda peruntukan atau kepanjangan, maka pendaftar pertama akan mendapatkan perlindungan dan hak ekslusif. Dan asas first to file principal bukan tanpa kekurangan, karena dapat digunakan oleh oknum yang memanfaatkan terlebih Dirjen HAKI belum melaksanakan penuh amanat pasal 21 ayat 2 a UU Merek.

\section{Saran}

1. Pendaftaran dengan nama merek terkenal harus tetap mengikuti prinsip first to file yang dianut undang-undang merek dengan cara melewati proses yang telah di tetapkan dengan memerhatikan asas itikad baik demi tidak terjadinya kasus serupa yaitu sengketa merek terkenal.

2. Diperlukan kerjasama yang harmonis antara pemerintah dengan disertai peraturan perundang-undangan yang memadai, aparat pemeriksa 
merek (Dirjen HAKI), aparat

penegak hukum, masyarakat

luas dengan informasi adanya

pelanggaran merek serta

pengusaha yang akan

menggunakan suatu merek

tertentu bagi produknya.

Sehingga pada prakteknya,

sistem pendaftaran First to

File dapat berjalan efektif

menciptakan keselerasan

jaminan keadilan dan

kemanfaatan, karena masih

banyak merek-merek yang

didaftarkan bukan oleh

pemilik merek yang

sebenarnya.

\section{DAFTAR PUSTAKA}

\section{A. Buku :}

Ahmadi Miru, Hukum Merek Cara Mudah Mempelajari Undang - Undang Merek. Jakarta : PT. Raja Grafindo Persada, 2005.

Arfi Dyah Chatarina, Perlindungan Pemilik Merek Pertama Pada Sistem Konstitutif. Hukum dan Dinamika Masyarakat. 16(2), 2019.

Iswi Hariyani. 2010. Prosedur Mengurus HAKI yang Benar. Yogyakarta : Pustaka Yustisia.

Khoirul Hidayah, Hukum HKI (hak kekayaan Intelektual). Malang : UIN Maliki Press, 2013.

Mas Rahmah, Perlindungan Hukum Merek Menurut UU 15
2001. Yuridika. 19(5), 2004.

Muhamad Djumhana dan R Djubaedillah. Hak Milik Intelektual (Sejarah, Teori dan Prakteknya diIndonesia), Citra Aditya Bakti, 1997.

Muhammad Djumhana, dan Djubaedillah, Hak Milik Intelektual, Bandung: Citra Aditya Bakti, 2003.

Ni Ketut Supasti Dharmawan dkk, Buku Ajar Hak Kekayaan Intelektual. Yogyakarta : Deepublish, 2016.

Sudargo Gautama dan R. Winata, Pembaharuan Hukum Merek Indonesia. Bandung : Citra Aditya Bakti, 1997.

Tomi Suryo Utomo, Hak Kekayaan Intelektual (HKI) di Era Global. Yogyakarta : Graha Ilmu, 2010.

Usman, Rachmadi, Hukum Hak Atas Kekayaan Intelektual. Bandung : PT.Alumni, 2003.

\section{B. Jurnal :}

Haedah Faradz, Perlindungan Hak Atas Merek. Jurnal Dinamika Hukum. 8(1).

Oksidelfa Yanto. Tinjauan Yuridis Uu No. 15 Tahun 2001 Tentang Merek : Sisi Lain Kelemahan Sistem First To File Dalam Perlindungan Hukum Atas Merek Sebagai Bagian Dari Hak Atas Kekayaan Intelektual (HaKI). ADIL 3(1), 2008.

C. Peraturan Perundang-Undangan :

Undang-Undang Nomor 20 Tahun 2016 Tentang Merek dan Indikasi Geografis.

D. Internet : 
Ana Sofiana, Perlindungan Merek Secara Internasional, Kompasiana, 13 Desember 2016. Di akses dari: Https://www.kompasiana.co $\underline{\mathrm{m} / \text { anasofiana/584fe751967a }}$ 612e13cc809d/perlidunganmerk-secara- Internasional/, Pada tanggal 08 Mei 2020 Pukul 19.00 Wib.

Anggar Septiadi. 2018. Merek Bensu Jadi Rebutan, ini kata Ditjen HKI. Diakses melalui https://nasional.kontan.co.id /news/merek-bensu-jadirebutan-ini-kata-ditjen-hki pada tanggal 08 Mei 2020.

Citta Nirmala Anindita Palupi. 2019. AKibat Hukum Penggunaan Nama Orang Terkenal Terhadap Merek Bensu (Bengkel Susu) Berdasarkanundang Undang Nomor 20 Tahun 2016 Tentang Merek Dan Indikasi Geografis. Skripsi. Jember : Universitas Jember.

Echa Cristi. 2020. Perlindungan Hukum Terhadap Pemilik Hak Atas Merek Berdasarkan Sistem First To File Principle (Studi Kasus: Putusan Mahkamah Agung Nomor 32 PK/Pdt.Sus-HKI/2018). Skripsi. Bandar Lampung : Universitas Lampung.

https://www.tempo.co/partner/uc_brows er/1135574/ini-alasanruben-onsu-ngotot-berebuthak-eksklusif-merekbensu?uc_news_item_id=17 81114415741286\&app=h5 card\&entry=browser\&entry $1=$ shareback_morearticle\&e ntry2=bottom_article diakses pada tanggal 08 Mei 2020.
Vincensius Binsar Ronny. Perkara Geprek Bensu vs Bensu. Diakses melalui https://www.vbr-andpartners.com/2019/06/13/pe rkara-geprek-bensu-vsbensu/ pada tanggal 08 Mei 2020. 